\title{
THE
}

\section{Small groups as context for institutional entrepreneurship: An exploration of the emergence of commercial microfinance in Bolivia}

Silvia Dorado

University of Rhode Island, sdorado@uri.edu

Follow this and additional works at: https://digitalcommons.uri.edu/cba_facpubs

Terms of Use

All rights reserved under copyright.

\section{Citation/Publisher Attribution}

Dorado, S. 2013. Small groups as context for institutional entrepreneurship: An exploration of the emergence of commercial microfinance in Bolivia. Organization Studies, 34 (4): 533-557.

This Article is brought to you for free and open access by the College of Business at DigitalCommons@URI. It has been accepted for inclusion in College of Business Faculty Publications by an authorized administrator of DigitalCommons@URI.For more information, please contact digitalcommons-group@uri.edu. 


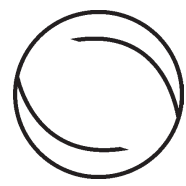

Small Groups as Context for

Institutional Entrepreneurship: An

Exploration of the Emergence of

Commercial Microfinance in Bolivia
Organization Studies 34(4) 533-557

(c) The Author(s) 2013

Reprints and permissions:

sagepub.co.uk/journalsPermissions.nav DOI: $10.1177 / 0170840612470255$

www.egosnet.org/os

\title{
Silvia Dorado
}

University of Rhode Island, USA

\begin{abstract}
This paper contributes to the emerging literature on inhabited institutions. It argues that institutional entrepreneurship, as most social action, is not an individual-bounded endeavor, at the hands of isolated individuals, but a group-bounded one, at the hands of social individuals inhabiting groups which motivate, inspire, and enable their engagement. The inhabited group-bounded conceptualization offered helps to overcome voluntaristic biases and atemporalism plaguing much micro research on institutional entrepreneurship. The paper builds on a qualitative case study of the emergence of commercial microfinance in Bolivia.
\end{abstract}

\section{Keywords}

inhabited institutions, institutional agency, institutional entrepreneurship, microsociology, small groups

\section{Introduction}

The engagement of individuals in institutional entrepreneurship has become a central concern in institutional research (Dacin et al., 2002). Research in this area has yielded a substantial body of knowledge (see, e.g., review by Battilana et al., 2009), but we still know little about why individuals get involved in these efforts. This question is central. Engaging in institutional entrepreneurship is a decision individuals are unlikely to take lightly, considering that, because of the difficulties involved, these efforts are expected to be both resource-intensive and risky (Phillips et al., 2000).

Most research exploring institutional entrepreneurship has adopted a macro perspective and focused on the institutional conditions that frame engagement (Dorado, 2005). This research has shown that individuals are more likely to get involved in institutional entrepreneurship when facing events with hard-to-disregard game-changing outcomes, such as technological disruptions (Greenwood \& Suddaby, 2006), regulatory and policy changes (Kellogg, 2009; Stark, 
1996), or a health crisis (Maguire et al., 2004). This research has also suggested that the likelihood of individual engagement is framed by the institutional logics that define the boundaries of fields (Greenwood et al., 2011). Institutional logics are broader cultural beliefs and rules that structure the cognition of individuals and guide their decision-making in a field (Friedland \& Alford, 1991; Ocasio, 1997; Scott, 2008; Thornton, 2004; Lounsbury, 2007, p. 289). Field boundaries are defined not by a single logic but a plurality of logics, and tensions and conflicts among them - variously precipitated by cracks, overlaps, and contradictions among logics - can trigger individual engagement in institutional entrepreneurship (Lounsbury et al., 2003; Rao, 1998; Seo \& Creed, 2002; Whittington, 1992).

A focus on macro-conditions (whether events with hard-to-disregard outcomes or tensions among institutional logics) advances our understanding of institutional entrepreneurship by explaining why individuals can become institutional entrepreneurs, not why they will. But without exploring why individuals will to get involved, it is difficult to understand why among individuals exposed to the same game-changing events, some work to preserve field logics while others engage in changing them (see, e.g., Barley, 1986). Neither can we explain why tensions among logics do not always fuel engagement and instead can be overlooked by the individuals experiencing them (see Zilber, 2002) and/or result in conflicts among individuals heralding different logics (Battilana \& Dorado, 2010; Glynn, 2000; Heimer, 1999).

Recently researchers have suggested the value of a micro-institutional perspective (Colyvas \& Powell, 2006) to explore differences in behavior among individuals exposed to similar macroinstitutional conditions (Binder, 2007; Hallett \& Ventresca, 2006; Lawrence \& Suddaby, 2006). This paper departs from this micro stand to explore the question of why individuals are willing to engage in institutional entrepreneurship in the context of the emergence of commercial microfinance in Bolivia.

The origin of microfinance is traced back to the founding of Grameen Bank, in the mid1970 s, which demonstrated that organizations lending to the poor could finance their social mission with the proceeds of their market-priced lending operations. The 1992 launch of Banco Solidario (BancoSol) in Bolivia marked the beginning of commercial microfinance. It differed from the model pioneered by Grameen in a revolutionary new way: BancoSol was a commercial and regulated financial institution and, as such, had a fiduciary responsibility toward depositors and investors. Since the founding of BancoSol, commercial microfinance has spread throughout the world (Nimal, 2004).

The grounded theory exploration conducted in this context showed that engagement in institutional entrepreneurship, as most social action, does not occur in a social vacuum (Becker, 1984). Institutions are inhabited (Hallett \& Ventresca, 2006) by social individuals. Institutional entrepreneurship is then not a lone endeavor but a social one. This means that institutional entrepreneurs do not act in isolation but in the context of social groups. All social groups are, of course, institutionally embedded but they are also unique contexts, with references tinted by their shared history of routine and serendipitous interactions and the social dynamics which link (e.g. interpersonal bonds) and distance (e.g. social status) their members (see also Fine, 2010). Groups can be of any size - a dyad qualifies and so does a baseball team (Fine, 2010; 1979) but they are small enough so that the individuals involved know each other as distinct individuals (Fine \& Harrington, 2004). Their boundaries and membership are fuzzy, but they have enough permanency so that, much like a "stage" (Fine, 2010, p. 356), groups provide a context which motivates, inspires, and enables engagement in institutional entrepreneurship.

This finding is consistent with research which has shown groups to be crucial both as "vehicles of socialization and social control" as well as "mechanisms of contestation and change" and "incubators 
of social change" (Fine \& Harrington, 2004, p. 314; Fine, 1979, 2010; Harrington \& Fine, 2000, 2006). Building on this coincidence, the paper argues both for an inhabited conceptualization of institutional entrepreneurship as a group- instead of individual-bounded process and for the adoption of the small group (Fine, 1979), the prototype meso-level unit of analysis (Fine, 2010), when exploring individual engagement in institutional entrepreneurship. The adoption of an inhabited group-bounded conceptualization advances research in institutional entrepreneurship in at least two relevant ways. First, it helps to overcome what Willmott (2011) has described as the voluntaristic bias of most micro-based research on institutional entrepreneurship. Adopting an inhabited understanding of institutional entrepreneurship suggests that social dynamics, such as interpersonal bonds (Korsgaard et al., 1995) and social-status competition (Weber, 1978), influence people's will to get involved in institutional entrepreneurship. Second, adopting the group as the unit of analysis of reference helps to overcome the lack of historicity of much research on institutional entrepreneurship (Lawrence et al., 2010), which produces a view of engagement as the product of punctual misalignments between individual interests and dominant logics. Specifically, it helps us see decisions to engage in institutional entrepreneurship as part of a path-dependent history of interactions, so engagements that outside of this path appear to be unwarranted and foolish (Aldrich \& Fiol, 1994) emerge within it as judicious next steps in a stream of decision-making.

\section{What the Literature Says About Individual Engagement in Institutional Entrepreneurship}

Most of what we know about institutional entrepreneurship discusses conditions that explain why individuals can become institutional entrepreneurs. On the one hand, researchers adopting a macrolens have argued that it is individuals' field positioning that allows and motivates engagement by framing their appreciation of how their interests are or are not aligned with field logics (Leblebici et al., 1991). Generally stated, these scholars have suggested that the interests of individuals centrally positioned in a field are likely to be aligned with institutional logics, and therefore these individuals will be motivated to engage in defending the status quo (Hensmans, 2003). Similarly, they have argued that the interests of individuals located at the fringe of a field are likely to be misaligned with field logics, and therefore individuals in these field positions have an incentive to get involved in efforts that run against the grain of field logics. On the other hand, researchers adopting a micro-lens on institutional entrepreneurship have, by and large, addressed the question of individual engagement considering the extraordinary skills and access to resources required to advance these efforts (Aldrich \& Fiol, 1994; DiMaggio, 1988; Rao, 1998).

An emerging body of work embracing situated perspectives (Emirbayer, 1997; Hallett \& Ventresca, 2006; Lawrence \& Suddaby, 2006) has begun to consider conditions that can explain differences in involvement among individuals facing similar circumstances (similar access to resources and field positioning; see, e.g., Barley, 1986; Binder, 2007; Espeland, 1998; Hallett, 2010). Rooted in the pragmatist (Dewey, 1985; Schütz, 1962) and symbolic interactionist (Blumer, 1986; Goffman, 1974; Mead, 1967) traditions, in this research, the status of individuals shifts from a role as "accomplice to social processes of institutionalization and structuration" (Giddens, 1984) to a role as "agent whose motivations, behaviors, and relationships" are central to their involvement (Lawrence et al., 2010, p. 55). Individuals inhabit local contexts (Hallett \& Ventresca, 2006), and their behavior varies depending on the peculiarities of these locals (Lawrence et al., 2010).

This research has yet to explore empirically the question asked in this paper: Why are individuals willing to engage in institutional entrepreneurship? Theoretically, this research points to dissonance (Festinger, 1957) as the answer (Emirbayer, 1997; Emirbayer \& Mische, 1998). 
Dissonance describes a cognitive state that people experience when their appreciation of situated circumstances violates their expectations of how things ought to be. This cognitive state is unpleasant and can under unusual circumstances generate surprise, puzzlement and thereby motivate individuals to engage in institutional thinking, that is, the type of reflective thinking that allows individuals to question their institutionally-defined expectations (Heclo, 2008; Stark, 2009). Nevertheless, a consideration of dissonance as the trigger for institutional thinking is at odds with a large body of both sociological (Meyer \& Rowan, 1977; Swidler, 1986) and social psychological research (Fiske \& Taylor, 1991; Weick, 1993). This research has convincingly argued that, when operating under conditions of dissonance, individuals are more likely to engage in selective interpretation so that the situation is emptied of its problematic content than they are to experience puzzlement and engage in institutional thinking. There is a need, then, for empirical research to further our understanding of the conditions influencing individuals' will to engage in institutional entrepreneurship.

This paper addresses this need and explores this question using a framework which suggests that individuals' will to engage depends on the co-presence of three conditions: (1) their identifying an opportunity for involvement, (2) their perceiving the risks and costs involved as worthy, and (3) their accessing the resources/support required. This three-pronged framework is well accepted in the institutional entrepreneurship literature (see, e.g., Aldrich \& Fiol, 1994; DiMaggio, 1988; Dorado, 2005) and facilitates a parsimonious analysis of the research question. Next, the paper introduces the research methods followed in exploring why individuals are willing to engage in institutional entrepreneurship, conducted in the context of the emergence of commercial microfinance in Bolivia.

\section{Research Methods}

\section{Data collected}

The author conducted more than 70 interviews, including interviews with all central firsthand participants, during several visits to Bolivia between 1997 and 1999 (list available upon request). Following grounded theory (Strauss \& Corbin, 1998), interviewees included not only individuals who championed the new commercial microfinance archetype (Greenwood \& Hinings, 1993), but also those who supported and resisted it, and even individuals who remained on the sidelines. All the critical participants were interviewed. The open-ended interviews averaged one-and-one-half hours and followed a protocol of questions that evolved with the research project (Strauss \& Corbin, 1998). Questions that persisted throughout the interview process included the following: Where did the original idea originate? How and when did you become personally involved in the project or initiative? How, when, and why did other people become involved? All but a handful of interviews conducted in public spaces where sound quality was too poor were tape-recorded and transcribed.

In addition, because the emergence of commercial microfinance in Bolivia had attracted the attention of development scholars, the research also benefited from rich archival material that facilitated triangulation and enabled the author to complement field data with case studies written before, during, and following the fieldwork. The study thus benefited from a historically informed understanding (DiMaggio, 1991; Rao, 1998; Schneiberg \& Clemens, 2006) of the individuals and organizations that launched the first commercial microfinance organizations. Among the documents collected were (1) case studies about microfinance in Bolivia (see, e.g., Christen, 1985; Fidler, 1998; Frankiewicz, 2001; Gloser, 1994; Gonzales \& Rivas, 1999; Gonzalez-Vega et al., 1996; Ramirez, 1998; Rhyne, 2001), (2) reports generated and statistical 
information collected by banking regulatory agencies (e.g. the Superintendencia de Bancos y Entidades Financieras, or SBFI, and Bolivia's central bank) and associations of organizations that lend to the poor (e.g. Asociación de Entidades Financieras Especializadas en Microfinanzas, or ASOFIN, and Asociación de Instituciones Financieras para el Desarrollo Rural, or FINRURAL), (3) technical reports published by donor organizations (e.g. Germany's Gesellschaft für Technische Zusammenarbeit, or GTZ), and (4) other professional reports.

\section{Analysis}

Analysis began with a simple narrative (Eisenhardt \& Bourgeois, 1988) summarizing the individual efforts that paved the way for the emergence of commercial microfinance. This was followed with a more in-depth exploration of individuals who founded and led organizations with features that went against the grain of the logics of the organizational archetypes (Greenwood \& Hinings, 1993) dominant in the field of provision of services to support the economic activities of the poor. These engagements were identified as instances of institutional entrepreneurship when they met three conditions:

(1) These individuals were involved in efforts that went against the grain of the logics governing the dominant archetypes.

(2) With their involvement, they assumed risks and costs beyond those regularly connected with their organizational position.

(3) They actively leveraged support and resources to advance these against-the-grain efforts.

The value of applying these three criteria became clear in an iterative process of dialogue theory and data (Ragin, 1994). This process showed that adopting these criteria helped to identify multiple instances of institutional entrepreneurship and to match the empirical evidence of these instances with three factors which, while enmeshed in the practice (and thereby the data), have been identified in the literature as influencing individual engagement in analytically distinct and relevant ways, i.e. motivation to engage, opportunity for engagement, and resources to advance engagement (Aldrich \& Fiol, 1994; Aldrich \& Ruef, 2006; DiMaggio, 1988; Dorado, 2005).

The next two steps of the analysis involved an exploration of these three factors to identify patterns in the seven instances of institutional entrepreneurship identified using the above criteria. The exploration revealed the influence on individual engagement of factors identified in the literature, namely, macro-conditions such as events with hard-to-disregard outcomes, logic tensions, and field positioning, and micro-conditions such as access to skills and resources. It also identified the influence of meso-level conditions that had been previously considered subsidiary in our explorations of institutional entrepreneurship, namely, social dynamics, including interpersonal bonds and status competition, and a history of social interactions. These conditions are introduced next to facilitate reading of the empirical evidence and findings.

In institutional literature, interpersonal bonds have been equated with social capital and identified as relevant for individual involvement in institutional entrepreneurship considering their role in facilitating access to resources and support to advance these engagements (see, e.g., Aldrich \& Fiol, 1994). The evidence suggested, however, that interpersonal bonds also can play a role in engagement by influencing people's motivations to get involved. It showed that, as suggested in other bodies of research in organization theory (see, e.g., Korsgaard et al., 1995), individuals' motivations to act are framed not only by their own interests but by those of others with whom the individuals have strong interpersonal bonds (Deutsch, 1949; Janis, 1982). 
Status competition describes decision-making following individuals' expectations on how their decisions will influence their social status (Weber, 1978). People derive status from material (e.g. a well-furnished home) and cultural or symbolic (e.g. familiarity with "high culture") assets (see Bourdieu, 1990; Veblen, 1970; Weber, 1978) and are said to win or lose status depending on their relative access to these assets. The influence of status competition on individual involvement in institutional entrepreneurship has seldom been acknowledged in the institutional literature (see Battilana, 2006; Washington \& Zajac, 2005, for noteworthy exceptions). Its influence, however, is well established in organization studies (see, e.g., Granovetter, 1978).

Finally, research on institutional entrepreneurship has discussed the influence of interactions on individual engagement (Hallett \& Ventresca, 2006; Lawrence \& Suddaby, 2006). Fundamentally, it has suggested that interactions can encourage engagement when they generate dissonance, thereby creating an opportunity for individual engagement in institutional thinking (Heclo, 2008). But as discussed earlier, this research still requires development to explain under what circumstances dissonance is likely to generate puzzlement and thereby engagement in institutional entrepreneurship, since individuals have a tendency to discard dissonance-generating events and information (Fiske \& Taylor, 1991).

The next two sections introduce the case and present the exploration conducted.

\section{The Emergence of Commercial Microfinance in Bolivia}

The emergence of commercial microfinance is considered an instance of institutional entrepreneurship because the features of this novel archetype (Greenwood \& Hinings, 1993) run counter to those defining the other organizational archetypes dominant in the provision of financial services to the poor in the late 1980s: state banks, credit cooperatives, and NGOs. Central among these features were the following:

- A focus on providing services to the urban poor and particularly street vendors and the like; the urban poor had never been the focus of state banks, credit cooperatives, or NGOs engaged in lending.

- Exclusive focus on providing financial services at the expense of other types of services, such as training and technical assistance (unlike NGOs).

- Lending practices defined by a manpower-intensive lending process (in order to evaluate loan risks and avoid borrower over-indebtedness) and insistence on loan repayment (unlike state banks, credit cooperatives, and even NGOs).

- Presence of an independent board of directors to oversee managers (unlike credit cooperatives, and NGOs).

- Financing of the lending portfolio with earned revenue, savings from the public, and commercial sources. (unlike NGOs).

- The inclusion of private investors as shareholders in organizations providing services to the poor (unlike NGOs, credit cooperatives, and state banks).

Figure 1 provides a graphic description of the emergence and evolution of the largest NGOs providing loans to the poor in Bolivia. Table 1 provides a brief but comprehensive chronology of this evolution. As shown in both, two NGOs, namely PRODEM (from now on BancoSol-NGO) and ProCredito (from now on Los Andes-NGO), pioneered commercial microfinance with the founding of BancoSol and Los Andes. They were followed by FIE-NGO which founded FIE and a group of NGOs which jointly founded Ecofuturo. Other NGOs, among them ProMujer and Crecer, 
continued to operate as NGOs and had never transitioned into commercial microfinance organizations. The next sections discuss in detail the efforts that drove this evolution with a focus on what motivated individuals to engage, how they identified the opportunity that inspired them, and how they accessed the resources that enabled them to realize their efforts.

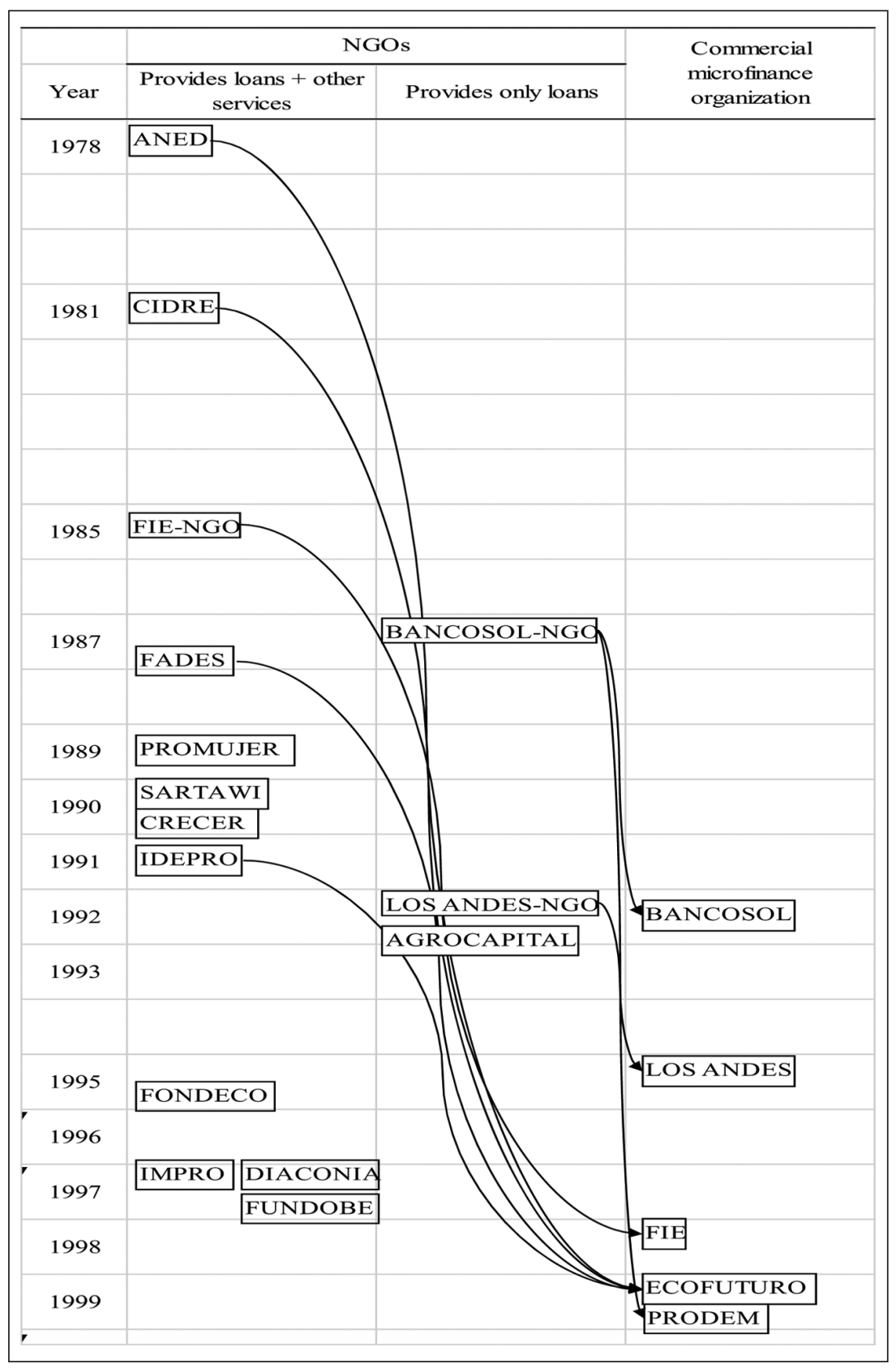

Figure I. Organizational origins and evolution of commercial microfinance. 
Table I. Chronology of the emergence of commercial microfinance in Bolivia (1987-1999).

1987

1990

1991

1992

1993

1994

1995

1997

1999
Under the leadership of Fernando Romero and Pancho Otero, BancoSol-NGO begins to operate. It is not only the first microfinance organization in the country but the first one devoted to providing loans to the urban poor in Bolivia.

Under the leadership of Eugenia Butron, Ivet Nava, Pilar Ramirez, and Pilar Velasco, FIE-NGO (founded in 1985) begins to provide loans to the poor. It serves urban areas but follows a traditional model of loan provision (it provides services other than lending and is not focused on financing its operations from earned revenue).

SARTAWI (founded in 1985) begins to provide loans. It follows traditional model. Under the leadership of Marcelo Zabalaga, FADES (founded in 1986) begins to provide loans in rural areas. It follows a traditional lending model.

Under the leadership of Carmen Velasco and Lynn Paterson, PROMUJER (founded in 1989) begins to provide loans to the poor in urban areas.

Under the leadership of Robert Ridgley, CRECER begins to provide loans in urban areas but out of major urban centers. CRECER adopts microfinance lending principles (interested in financing through earned revenue) but focused on providing services other than credit.

Under the leadership of Roberto Casanovas, IDEPRO (founded in 1986) begins to provide loans in urban areas. Adopts microfinance lending principles (interested in financing through earned revenue) but focused on providing services other than credit.

Under the leadership of Luisa Revilla, CIDRE (founded in 198I) begins providing loans to the poor in rural areas. It follows traditional model.

Under the leadership of Fernando Romero and Pancho Otero, BancoSol-NGO

launches BancoSol, the first commercial microfinance organization.

Under the leadership of Pilar Velasco, Los Andes-NGO begins operations. It is earmarked to transition into a commercial microfinance organization.

FIE-NGO adopts microfinance lending principles except credit only.

Founding of the FINRURAL association created to represent the interest of microfinance organizations that wished to remain as NGOs. Its associates include ANED, FADES, FONDECO, PRODEM, SARTAWI, and CRECER.

FADES adopts microfinance principles except credit only.

Under the leadership of Gustavo Biruet, ANED (founded as an association of NGOs in 1978) adopts microfinance principles except credit only.

Los Andes-NGO launches the commercial microfinance organization Los Andes, PFF (private financial fund).

The leaders of FIE-NGO (except Pilar Velasco now leading Los Andes) launch FIE, PFF.

Under the leadership of Eduardo Bazoberry, BancoSol-NGO launches another commercial microfinance organization (PRODEM, PFF).

The leaders of FADES, CIDRE, ANED and IDEPRO launch a commercial microfinance organization named Ecofuturo, PFF.

A group of commercial microfinance organizations including BancoSol and Los Andes launch ASOFIN, an association devoted to defending the interests of commercial microfinance organizations. The group includes only regulated organizations devoted to microfinance (BancoSol, Los Andes, FIE, Ecofuturo, and PRODEM) and NGOs with the intention of becoming regulated institutions (e.g. Agrocapital). 


\section{Launching of BancoSol-NGO and subsequent launching of BancoSol}

Bolivia's urban poor had traditionally relied on loan sharks, pawnshops, and pasanaku ${ }^{1}$ brokers for their working-capital needs. This reliance began to diminish when Fernando Romero launched BancoSol-NGO in 1987. Considering the hard-to-disregard game-changing conditions (Greenwood \& Suddaby, 2006) that Bolivia was undergoing at this time, the fact that NGOs began to provide loans to the poor at this time appears unsurprising. Between 1980 and 1985, Bolivia's GNP fell by nearly $10 \%$, and inflation reached a historical high of 24,000\% (Jemio, 1999). At the time, Paz Estenssoro (1985-1989) was leading the country, and, under the advisement of the International Monetary Fund and the World Bank, his administration adopted drastic measures to deal with this unprecedented crisis. One measure was the closing or restructuring of state-owned companies, which was expected to result in sharp increases in unemployment. In this context, there was an urgent need for programs to support the economic activities of the poor, including facilitating their access to loans.

But whereas the launching of NGOs to provide loans to the poor was not surprising, it was surprising for any NGO to have someone with the profile of Fernando Romero as founder and for it to have most of the features which we now associate with microfinance - those listed earlier except the two last ones (financing of the lending portfolio with commercial sources and private ownership).

Fernando Romero possessed the ideal profile of an institutional entrepreneur (DiMaggio, 1988). "An eclectic and vigorous entrepreneur with an intellectual bent" (Rhyne, 2001, p. 63), he had the requisite social assets and political skills to champion this pioneering NGO. But, in the context of Bolivia, the involvement of any businessman in the NGO field, including Romero, was, to say the least, unusual. As Sanchéz de Lozada, former president of Bolivia, observed, "Bolivia has no Anglo-Saxon tradition of philanthropy. We've got confession to get us to heaven" (Rhyne, 2001, p. 64). Moreover, Romero had, at this time, little understanding of what microfinance was. He had no problem with the idea of BancoSol-NGO serving the urban street vendors, unaware of how this ran against the grain of the practices dominant in the field. But the motivation for his involvement was philanthropic and he was shocked when he realized that BancoSol-NGO was charging interest rates that were about three times those charged by regular financial institutions in Bolivia (around 45\%). So why did he lead the founding of BancoSol-NGO? All interviewees, including Romero himself, answered this question by pointing out how he was convened (Dorado, 2005) to do so by Jack Duncan, the chairman of Acción International's board, with whom he shared both a long history of interactions and a personal friendship. Recalled Romero:

I met with Duncan, who was the first person I worked for when I graduated from MIT, in WR Grace \& Co., and Jack told me: "We are developing a small institution in Boston that is called Acción where we are putting together some money to give credit ..." And I said, "Okay, send me one of your guys." (interview, 24 April 1998)

Romero would participate as chairman of the board and help the organization leverage local resources, Acción International's staff would provide the operational know-how, and a carefully selected NGO professional would run the organization. Fatefully, the professional hired for the job was Francisco (Pancho) Otero. In the next quote, Otero explains how he was hired for the job.

This period [the period he spent working with lending organizations in rural areas] lasted about 10 years, and it is when I learned a lot of things about providing loans to "excluded" people [those not being served by the local institutions]. Then, in the year ' 86 , is when Acción International approaches me to run [...] at 
the same time my sister Maria joined the organization in Honduras [...] she had gained their trust, and they said, "Your brother, what do you think?" and she said yes. (interview, 24 March 1998)

Under Otero's leadership, BancoSol-NGO succeeded beyond anyone's expectations. Regardless of the high interest rates it charged, "people would wait for hours, around the block, to get a loan" (interview with regional manager, 25 April 1998). By 1991, BancoSol-NGO had 22,700 loans outstanding, a portfolio of $\$ 4.6$ million, and an absurdly low loan-repayment default rate of $0.0002 \%$ (see Frankiewicz, 2001, for a detailed review of PRODEM's operations in these early years). Moreover, its client base was growing at a surprising 50\% per year (Rhyne, 2001).

BancoSol-NGO's uncanny success came as a surprise to all involved. Nobody had realized the pent-up demand for loans among Bolivia's poor. The loans BancoSol-NGO was offering were indeed expensive, but poor borrowers had no access to regular bank loans. BancoSol-NGO's loans, when compared with the informal sources accessible to poor borrowers (e.g. loan sharks, pawnshops), appeared reliable and even affordable. (The $45 \%$ interest rate charged by BancoSol was well below half that charged by the informal lenders serving the poor.) Romero, who owned a commercial bank, regarded BancoSol-NGO's success with disbelief. He asked Otero to take him on a field visit to learn firsthand who these people were that were borrowing and repaying their loans; BancoSol-NGO's repayment rates were close to $100 \%$, a figure unheard of in the country, even among its most reputable financial institutions.

Interestingly, BancoSol-NGO's uncanny success generated an unexpected problem: Donor funds, the conventional source of financing for NGOs, were woefully inadequate to fuel the organization's fantastic rate of growth. BancoSol-NGO's leadership had to revert to its members' personal wealth just to keep up. Recalled one member of BancoSol-NGO's management team:

I remember going personally to the banks I knew and asking them for loans. First I would ask them to use [BancoSol-NGO's] loan portfolio as guarantee. But they would say no and ask for other assets, and I would propose someone's jewelry, my father's house. Pancho mortgaged his house; we all mortgaged things to get money [...] what the donors were giving was just not enough. (interview, 23 April 1998)

BancoSol-NGO's operational success, then, can be fairly described as a moment of dissonance (Festinger, 1957). Its success and the financing difficulties it generated created an opportunity for institutional thinking (Heclo, 2008). Interestingly, consistent with institutional theory insights (Meyer \& Rowan, 1977), the group of individuals involved, namely Acción's staff, Otero, and Romero, discussed and generated ideas which, while testing their boundaries, followed by and large the dominant financing logics.

Acción's staff, within their role as NGO experts, suggested a system of loan guarantee letters that BancoSol-NGO could use to get loans from local banks. The source of the guarantee funds was the same - donations - and thus this solution did not break with the dominant donations-based model. Otero, the local NGO professional managing the organization, did not offer any specific solution. He did suggest, however, that it was "a big mistake" to try to alleviate BancoSol-NGO's financing problems with guarantee letters or any other instrument dependent on donors: "Every year we have to go out with the hat to get money to finance [our] growth" (interview, 24 April 1998). He talked "to anyone willing to listen" (interview, 23 April 1998) about the need to grow BancoSol-NGO so that it could "masificar" microfinance, i.e. extend access to all.

Romero shared Otero's dislike for the need to "pass the hat" to get donor financing, a painful reminder of Bolivia's dependency on the whim of donors. But at this point in time he was rather disengaged from the organization. Disengagement was, in fact, the norm for all the businessmen 
who sat on BancoSol-NGO's board, as a manager from BancoSol-NGO commented: "Board meetings happened over lunch, and dessert would arrive before discussing BancoSol-NGO" (interview, 24 April 1998).

An unexpected and fateful interaction with Martin Connell, a member of Acción's board, redefined the group's thinking. As leaders of BancoSol-NGO, Otero and Romero were part of Acción's network and had traveled together to New York to attend Acción's 1989 board meeting. Connell invited them to join him for dinner. During the meal Connell said:

$[\ldots]$ we need to create a bank. The interesting example [...] was done at the end of the 19th century by Crédit Agricole. [...] They used the bakers and gave them a little box. [... T] his will be difficult in Latin America [...] We have to imitate McDonald's. (interview, 24 April 1998)

Much like the generative metaphor described by Mary Douglas (1986) and Donald Schön (see 1979), this piece of institutional debris (Schneiberg, 2007) put BancoSol-NGO's uncanny success and its financing difficulties in perspective for Romero and Otero. Crédit Agricole had extended access to loans by working with local bakers; Connell thought BancoSol-NGO could accomplish this by franchising like McDonald's. Back in Bolivia, an energized Romero and Otero engaged in institutional thinking (Heclo, 2008), discussing their options. They settled on a plan to launch a commercial microfinance bank. They reasoned that with the creation of a commercial bank, BancoSol-NGO would, like Crédit Agricole, be able to access commercial funds, including deposits, and in this way it would be able to solve, once and for all, its fund-raising difficulties. But they had to convince Acción's staff to support their actions. Acción's staff - all NGO professionals were reticent. They worried that the commercial transition could, in time, push BancoSol to abandon its social mission. They were also concerned about the impact on Acción itself. Restrictions on the ability of US-based not-for-profit organizations to invest in for-profit endeavors constrained Acción's ability to invest in the future bank: "[They said,] 'Look, we can get you a donation of $\$ 5$ million, but do not ask us to invest $\$ 100,000$ because it means accountability, and it is for-profit, and we do not have the situation"” (interview, 24 April 1998).

Romero's point of view prevailed, but only when he turned his request into a personal appeal building on his long-standing bond with Acción's chairman (Duncan) and the newly formed one (through their work in BancoSol-NGO) with Acción's general manager (Bill Burrows). As Romero commented: "This exception, they took it, because I insisted personally with Jack Duncan and also with Bill Burrows" (interview, 24 April 1998). With the counsel of legal experts, Acción defined a solution that allowed it to invest in BancoSol. With this agreement, Romero, Otero, Connell, and Acción's leadership began the arduous negotiations necessary to leverage the financial support and regulatory changes required to launch a commercial bank devoted to providing microfinance services. They succeeded, and the commercial microfinance bank Banco Solidario (BancoSol) commenced operations in February 1992.

\section{Plans to launch a development microfinance organization}

The professionals leading the other Bolivian NGOs also witnessed BancoSol-NGO's success in disbelief. Like Romero, they wondered why people were queuing for hours to get a $45 \%$ interestrate loan. But these professionals did not use this moment of dissonance as an occasion to launch a commercial microfinance organization. Even though the NGOs they headed were involved in providing loans, they did not identify themselves as lenders but as development professionals. From this perspective, BancoSol-NGO's unique features, such as targeting street vendors, charging 
high interest rates and insisting on repayment, were inappropriate, and its plan to form a commercial bank with owners who could privately benefit from its operations was unwarranted and illegitimate.

A group of them - namely, the leaders of ANED, CIDRE, FADES, FIE, and Sartawi - began discussing an alternative institutional entrepreneurship opportunity: the launching of a development microfinance organization. All local NGO professionals saw BancoSol-NGO's formation of BancoSol as inappropriate, to say the least, and most remained disengaged. But this group had emerged when these individuals worked together in the launching of FADES, an NGO devoted to providing loans to farmers. From this social platform the launching of a development microfinance organization appeared as a reasonable response. The organization they envisioned would follow up on their design for FADES. Like FADES, it would have an independent board of directors, populated not by businessmen and/or private investors but by themselves, and it would finance its portfolio with donor funds. It would adopt those microfinance innovations that did not conflict with NGO logics, such as microfinance's manpower-intensive approach to loan evaluation. But it would have a large portfolio of loans in manufacturing and agriculture and would not charge the high interest rates of BancoSol, have private investors, or provide services other than credit.

This group's plan to launch a development microfinance organization did not progress. In a fateful moment, later referred to by interviewees as the "Los Andes fiasco", their conversations were unexpectedly sidetracked when C.-P. Zeitinger, founder of Internationale Project Consulting gmbf (IPC), approached them with the proposal to work with IPC to launch an NGO-founded commercial microfinance organization. Initially Zeitinger's invitation was welcomed. As one participant observed, it was perceived as "an opportunity not to have to do this alone [by themselves]" (interview, 14 April 1997); after all, he had already secured funds from the GTZ to finance the project. But this enthusiasm was short-lived.

Central to Zeitinger's project was the idea of self-sufficiency, which he thought would be possible only if the organization provided only credit and focused initially on serving urban areas (e.g. street vendors). The group disagreed with his assessment, which they perceived as overly intrusive: "He would get involved in areas of decision-making that are out of the scope of a consultant" (comment by one of the NGO leaders involved; interview, 18 March 1998). They wanted his know-how and the funds from the GTZ, but they did not want him to change their plan. He insisted, and as a result his proposal was rejected by all except Pilar Velasco, at the time the acting general manager of FIE-NGO. Not surprisingly, her decision cast her, and by extension FIENGO, as social deviants (Goffman, 1963). The decision, however, allowed Zeitinger's initiative to continue.

\section{Plan to launch a commercial microfinance organization with FIE-NGO, which led eventually to the launching of Los Andes}

Zeitinger began his consulting engagement with FIE-NGO immediately, but it was short-lived. FIE-NGO's leaders were four women (Maria Eugenia Butrón, Ivet Nava, Pilar Ramirez, and Pilar Velasco) who had begun to provide loans the same year BancoSol-NGO was founded, and with financing from the InterAmerican Development Bank they had built a rather healthy loan portfolio. Pilar Velasco had led the idea of engaging Zeitinger and the other women had gone along, but they soon began to have second thoughts. Zeitinger adamantly insisted that FIE-NGO should change its board of directors to include individuals with a high social profile in the country. Recalled one member: "He would say, 'You are a group of mere housewives, and no one is going to want to hear what you have to say. You need an umbrella of important people [on the board]" (interview, 11 April 1997). FIE-NGO's founders worried about its implications for their own ability to control the 
future of FIE-NGO. Since most had no background in finance (or any other field connected with business lending), it was possible for the new board to consider them unqualified and ask them to leave, with little regard for their role in and contribution to the building of FIE-NGO.

Following their disagreement and distrust, the group decided that FIE-NGO should stop working with Zeitinger. They wanted to keep the funds that the GTZ had earmarked for the project but they would ask the GTZ to engage a different consultant to work with them. As one member recalled, "[W]e began questioning why this man [Zeitinger] wants to do this to us.... [T] hen, on a Sunday, we said, 'Leave us; we are going to keep going alone without you'" (interview, 11 April 1997). Pilar Velasco disagreed, but when she failed to convince the other group members she decided that the only logical thing to do was for her to resign from FIE-NGO. This was a difficult decision. Already written off as an outcast by the local NGO leaders with whom she had worked, she was also now self-excluding herself from FIE-NGO, her home institution which she had helped to found and which was her main source of income.

Impressed by Velasco's bold decision, Zeitinger invited her to present with him a reformulated version of the project to the GTZ. In this new version the GTZ funds would be used to launch a brand-new NGO earmarked to transition into a commercial microfinance organization (the prior project involved working with an existing local NGO). Together they rushed to the offices of the GTZ in La Paz. Rather dramatically, they arrived a few hours before FIE-NGO's leaders could present their own request for a new consultant. They were granted permission to use the funds earmarked for the project to launch the new NGO.

In 1992, working now with Zeitinger and his consultants from IPC, Velasco assumed leadership of this new effort. She leveraged the support and participation of friends and relatives who could act as an "umbrella of important people" and launched Los Andes-NGO. In 1995, after arduous work and negotiations with the regulatory authorities, Los Andes-NGO spun off from Los Andes. The interpersonal bonds of the umbrella of important individuals that Velasco had attracted played an important role in their successful lobbying for the new legislation (Decree 24,000, creating Private Financial Funds) needed to launch Los Andes as a commercial microfinance organization, as shown in the following comment:

Mr. X [a member of the Los Andes-NGO board] has an important level of social standing. He is in the Chamber of Commerce and has access to the leadership of the SBFI [banking regulatory agency] without having to go through secretaries or setting up audiences. (interview, 16 March 1998)

\section{FIE-NGO's members decide to launch a commercial microfinance organization}

While Velasco worked to build Los Andes, her ex-peers at FIE-NGO decided to launch their own commercial microfinance organization. The group was fueled by their sense that, without access to the commercial funds available to commercial organizations (which BancoSol and Los Andes were enjoying), FIE would not be able to grow its portfolio as rapidly and would unwarrantedly lose its status vis-à-vis Los Andes (see Table 2). Consider the following comment by the leader of one of these NGOs: "Los Andes was growing [...] and then we said, 'If we do not risk it and continue, we are going to remain a very small thing that at some point was a good idea and stay there"' (interview, 11 April 1997).

In their founding of a commercial microfinance organization, FIE-NGO's leaders had hoped to avoid having businesspeople on their board of directors - the suggestion that sparked their disagreements with Zeitinger - but the regulatory agency insisted. As the group grew convinced that they could not continue without assenting to this request, they agreed to assume the risks associated (their losing control over the organization and potentially their jobs) and identified a private 
Table 2. Comparative evolution of selected microfinance organizations in Bolivia (portfolio outstanding in $\$ 000)$.

\begin{tabular}{lccccccc}
\hline & 1992 & 1993 & 1994 & 1995 & 1996 & 1997 & 1998 \\
\hline BancoSol & $8,800^{*}$ & 24,800 & 33,200 & 36,700 & 47,400 & 63,100 & 74,068 \\
Los Andes & 711 & 1,362 & 2,863 & $6,049 *$ & 11,880 & 20,430 & 28,614 \\
FIE & 2,082 & 3,108 & 4,159 & 5,881 & 7,694 & 12,127 & $16,700^{*}$ \\
IDEPRO & N.A. & N.A. & N.A. & N.A. & 2,383 & 5,003 & 7,343 \\
CIDRE & N.A. & N.A. & N.A. & N.A. & 921 & 919 & 1,148 \\
FADES & N.A. & N.A. & N.A. & N.A. & 5,200 & 6,512 & 9,047 \\
ANED & N.A. & N.A. & N.A. & N.A. & 4,535 & 5,808 & 6,451 \\
\hline
\end{tabular}

Source: Boletín Financiero (1997, 1998, 1999) and annual reports (BancoSol, Los Andes, FIE-NGO).

*Year in which the organization transitioned into a commercial financial organization.

investor in Mr Johnson, a local industrialist, and invited him to join them. FIE-NGO launched its own commercial microfinance organization in 1998. Interestingly, the Private Financial Fund legislation that the Los Andes-NGO founding group had lobbied into existence allowed FIENGO's founding group to gain the financial support and regulatory approval required to launch their own commercial microfinance organization in 1998.

\section{Local NGO professionals re-ignite efforts to launch a development microfinance organization and decide to form a commercial microfinance organization}

The group of leaders of the other NGOs involved in the Los Andes fiasco (ANED, CIDRE, FADES, and Sartawi) followed their own path and continued to be involved in two institutional entrepreneurship efforts, namely a new plan to create a development microfinance organization and a plan to launch their own commercial microfinance organization.

In 1993, taking advantage of the Bolivian Congress's work on drafting new banking legislation, the group spearheaded lobbying efforts for regulatory changes tailored to their vision for a development microfinance organization. These changes would allow organizations engaged in lending to the poor to capture savings and deposits without requiring them to become for-profit or have private investors, although they could have municipality governments as investors. Their idea was that with access to deposits and, if needed, public investment, they would be able to access sufficient funds and keep up with the growth of BancoSol and Los Andes but without undermining what they called "the human side of microfinance" - their freedom to decide who and how to serve, prioritizing clients' human needs over financial concerns.

Interestingly, in parallel with these lobbying efforts, three of them (the leaders of ANED, CIDRE, and FADES) formed another group joining forces with the leaders of two other local NGOs (IDEPRO, which had participated in the conversations to launch a development microfinance bank, and UNITAS, an umbrella NGO providing financing to all of these NGOs), to launch together a commercial microfinance organization. When asked about their participation in groups with parallel and apparently contradictory initiatives, these individuals argued that it was the only way they could retain their competitive position. In the words of one of them:

[Commercial microfinance] is the future, but we are resisting it so it would have a human face and not a monetary face. [...] Maybe tomorrow, the group in power will decide that the NGOs are not going to do microfinance anymore. [...] In that case, we are out of the battle. It is for that reason that we are in Ecofuturo: to fight also from the side of PFFs [Private Financial Funds]. (interview, 17 March 1998) 
The efforts of the group working in the development microfinance organization related plan were only partially successful. The Bolivian Congress included the desired language in the new law, but the banking regulatory agency stalled on developing this language into specific legislation. But the efforts of the group to launch a commercial microfinance organization prospered, and this group launched Ecofuturo in 1999.

In ending this brief narrative, it is interesting to note that there were several local NGO professionals who, while affected by the emergence of commercial microfinance, did not get involved in institutional entrepreneurship. Among them were the leaders of ProMujer and Crecer, two of the most successful local NGOs providing microfinance. ProMujer's leaders were a local Bolivian and an American living in the United States. Crecer was a foreign implant that belonged to an international network of organizations that provided services to the rural poor around the world. It was led by a foreigner with no ties to the leaders of local NGOs.

In contrast with the group of NGO leaders who got involved, these individuals were engaged in alternative groups with pasts which did not include the founding of FADES or discussions to create a development microfinance bank. Their lack of involvement in FADES explains their disengagement from the local NGOs' discussions to launch a development microfinance bank. Their lack of involvement in these discussions, in turn, explains why they never perceived Los Andes as a suitable referent for their status calculations. The leaders of ProMujer and Crecer continued to successfully grow their organizations. They adopted microfinance practices selectively, consistent with their own organizational identity, but they did not assume risks or costs beyond those necessary to advance their mission or leverage resources and support for projects that ran against the grain of the logics of the dominant organizational archetypes (Greenwood \& Hinings, 1993). In short, they were successful, entrepreneurial individuals, but they did not become invested in the advancement of any one organizational archetype.

By 1997, a street vendor in La Ceja, one of the busiest street markets in Bolivia, was receiving up to three visits a day from loan officers offering credit. Of note, the Private Financial Fund legislation lobbied for by Los Andes was not only used by NGOs to launch commercial microfinance organizations but also co-opted by private investors to launch for-profit consumer lending ones. By 1999 the growth of these consumer lenders, with their disregard for the risks of overindebting clients, created a repayment crisis that threatened the survival of most organizations lending to the poor in Bolivia. Following this crisis, these consumer lenders closed their doors, but, at the time of writing this paper, all the organizations covered in this study (BancoSol, Los Andes, FIE, Ecofuturo, ProMujer, and Crecer) had survived the crisis and were still thriving. Poverty continues to be a significant problem, yet Bolivia's poor, both in urban and in rural areas, have unprecedented access to financial services, and the interest rates they pay for loans, while still quite high, have fallen substantially. In 2012, they averaged around $18 \%$ - about one-fifth of what they had to pay to loan sharks and pawnshops, their only sources of financing prior to 1987.

\section{Findings: Groups as the Stage for Institutional Entrepreneurship}

Commercial microfinance emerged and developed in Bolivia at the hands of groups of individuals who, with their successful and failed institutional entrepreneurial efforts, introduced and mainstreamed this novel organizational archetype (Greenwood \& Hinings, 1993). Two groups launched commercial microfinance organizations (BancoSol-NGO and BancoSol, and Los Andes), and their actions paved the way for others to launch new commercial microfinance organizations (FIE and Ecofuturo). Two others tried but failed to launch an alternative archetype (a development microfinance organization), and their failure further solidified the position of commercial microfinance as 
a legitimate organizational archetype for providing financial services to the poor. A parsimonious look at these efforts suggests that the interactions and social dynamics that made up these fuzzilybounded groups acted much like a "stage" (Fine, 2010, p. 356) which motivated, inspired, and enabled the engagement in institutional entrepreneurship of these groups and/or their members.

\section{Motivating engagement}

The institutional literature has explained individual motivation to engage in institutional entrepreneurship considering how field positioning defines the alignment or lack thereof between an individual's interests and field logics (Hensmans, 2003; Leblebici et al., 1991). The evidence supports the influence of field positioning but also suggests that the social dynamics framing individual relations within their group stage crucially influence their perceptions of alignment beyond field positioning.

The groups involved in launching commercial microfinance organizations were positioned at the fringe of the field. The creation of BancoSol-NGO was led by a group that included the chairman of a US-based international NGO (Jack Duncan) and a member of Bolivia's business elite (Fernando Romero). Duncan was acting on behalf of Acción International, advancing this organization's agenda of expansion. Without the benefit of additional evidence, it is difficult to explain his engagement beyond his organizational role and field positioning. But he was not leading the effort; that person was Romero, his protégé, who, with little understanding of microfinance, agreed to lead the launching of BancoSol-NGO. Romero's acceptance was framed by his concern for the need to alleviate the impact of structural adjustment on the poor. In Bolivia, however, the likelihood of a member of the economic elite forming an NGO was small. They got involved in social issues by assuming positions in government or financing church-based charities, not by launching NGOs. Accordingly, it is unlikely that Romero's general concern for the poor would have materialized in his assuming the risks and cost of launching an NGO outside the group stage created by his interactions and interpersonal bonds with, first, Duncan and subsequently the individuals who worked with him in BancoSol-NGO, i.e. Bill Burrows (Acción) and Pancho Otero.

In the case of Los Andes, the so-called Los Andes fiasco had positioned C.P. Zeitinger and Pilar Velasco at the fringe of the NGO field. But their field positioning only partially explains the motivation of this tight small group. Instead, it is more easily explained by the interactions accompanying the fiasco. Zeitinger's motivations can be easily understood by focusing on his organizational role, but not Ms Velasco's - the eventual leader of the initiative. Her willingness to assume the risks and costs involved emerged from the interactions and decisions that created and followed the fiasco and particularly her decision to quit FIE. Only by considering these interactions can we explain her accepting Zeitinger's invitation to request and use funds already earmarked for FIE to launch Los Andes and her calling on her friends and family to support her in this endeavor.

The other initiatives were carried out by two overlapping groups of field insiders. As in the case of field outsiders, field positioning emerges only as a partial explanation for their engagement. Instead, the two overlapping group stages housing these individuals explain why these NGO professionals and not others engaged. The groups had emerged from past interactions which led to the launching of FADES and were buttressed when their efforts to launch a development microfinance organization derailed. From this stage BancoSol and particularly Los Andes stood as relevant status referents (Weber, 1978) and their fantastic operational success as a source of status loss. The wish to regain status vis-à-vis BancoSol and Los Andes fueled the groups' will to assume the risks and costs involved in advancing plans that would allow them to regain the lost status, i.e. lobbying 
for regulations that would support the launching of development microfinance organizations and launching of a commercial microfinance organization. Absent from (or out of) these overlapping groups NGO leaders did not consider BancoSol and Los Andes as relevant status referents and therefore lacked the motivation to engage in institutional entrepreneurial efforts. This insight, which suggests that individuals' past interactions influence who are perceived as relevant status referents, and thereby individuals' motivations for action, is consistent with social psychological research exploring the influence of identity and status competition on decision-making within organizations (see, e.g., Ibarra et al., 2005).

\section{Inspiring opportunity identification}

As suggested in the institutional literature, individual appreciation of opportunities to engage in institutional entrepreneurial efforts was facilitated by macro-conditions with hard-to-disregard outcomes (Greenwood \& Suddaby, 2006), such as Bolivia's hyperinflationary crisis, and tensions in field logics (Whittington, 1992), such as those generated by the financial constraints experienced by BancoSol-NGO. Engagement was also facilitated by a micro-factor, namely, the dissonance (Emirbayer, 1997) generated by the unexpected and uncanny operational success of BancoSol-NGO. These macro- and micro-conditions provided ground for opportunity identification, but who perceived in these conditions an alignment with their individual interests so as to justify their engagement in institutional entrepreneurship is better explained by looking at how these macro- and micro-conditions interplayed in the meso-group stage.

First, Romero's initial involvement in the launching of an NGO with unusual attributes (BancoSol-NGO) did not follow from the identification of an opportunity but by his being convened to engage by Jack Duncan, with whom he shared a lengthy history of interactions and a personal friendship. But Romero's later engagement in launching the commercial bank BancoSol emerged within a group stage which now included not only Mr Duncan but also the other members of Acción's staff and Pancho Otero. It occurred in the milieu of the financing difficulties created by the unexpected and uncanny operational success of BancoSol-NGO, but it was fueled by Otero's interpretation of BancoSol-NGO's success as an opportunity to democratize access to loans in Bolivia, and it was irremediably kindled by the interaction with Connell, who unveiled the surprising parallels between BancoSol-NGO and Crédit Agricole.

Second, the initiative to develop Los Andes can be traced back to plans that Zeitinger and his staff at IPC had defined prior to their involvement and, therefore, can also be explained without reference to the meso-group stage. However, it required the involvement of Pilar Velasco in order to progress. Only with her engagement as leader of the initiative could it advance. But the engagement of someone with Ms Velasco's profile can only be explained considering the group stage in which she was operating. The launching of a brand new NGO from scratch ran against the grain of dominant practices - something that both Zeitinger and Velasco, aware of its illegitimacy, dismissively described as an exercise in "artificial insemination". The engagement of both Zeitinger and particularly Velasco in such a deviant initiative is hard to imagine outside the tight grouping of Zeitinger and Velasco after her decision to abandon FIE-NGO.

Third and finally, as mentioned earlier, the other initiatives were led by groups of field insiders. The literature on the influence of field positioning suggests that these individuals were likely to get involved but only in defense of the dominant archetype that housed them (NGOs). The evidence, however, shows that they did not work to protect the established archetype and instead engaged in advancing an alternative although related archetype, namely a development microfinance 
organization. The features of the development microfinance organization were close to that of the dominant archetype, but they still differed from it in relevant ways.

The group stages created by these professionals' history of interactions crucially explains their inspiration to engage first in launching a development microfinance bank as well as their later engagement in the launching of a commercial microfinance plan. The development bank plan can be explained considering the history of interaction of the group, which placed FADES, and not Crédit Agricole, as the relevant historical referent. The commercial microfinance plan can be explained considering changes in members' shared understandings sparked by the Los Andes fiasco, which placed two commercial financial institutions (BancoSol and Los Andes) as relevant operational referents for the provision of financial services to the poor.

\section{Enabling access to resources and support}

Finally, as has been previously argued in the literature (see, e.g., Aldrich \& Fiol, 1994), the evidence does suggest that the interpersonal bonds facilitated access to resources and support and thereby enabled institutional entrepreneurship. The launching of BancoSol-NGO and BancoSol was enabled by the wealth of international know-how and access to international donors brought by Duncan and his staff from Acción. They were also enabled by Romero's access to local sources of financing as well as his reputation as a successful businessman. In turn, the launching of Los Andes was enabled by the know-how and access to financing brought by Zeitinger and his staff as well as the network of family and friends brought by Velasco, crucial in negotiations for regulatory approval.

Interestingly, the evidence suggests that individuals may engage in institutional entrepreneurship even in the absence of an enabling group stage. But it also suggests that without this stage efforts are likely to fail. Efforts to advance the development microfinance archetype failed largely because individuals could not mobilize funds or regulatory support. Moreover, the later efforts of these individuals to early-adopt the commercial microfinance model with the launching of FIE-PFF and Ecofuturo were possible not because the group stage of its founders enabled their accessing the required resources and regulatory support but because supporting these endeavors had become institutionally acceptable following the launching and operational success of BancoSol and Los Andes.

In summary, the evidence does not disconfirm that macro- and micro-conditions allowed individuals to become institutional entrepreneurs. But it suggests that we can explain why individuals facing similar macro-conditions and with similar micro-profiles have a different likelihood of engaging in institutional entrepreneurship considering the interplay of macro- and micro-conditions in the meso-group stage. Engagement in institutional entrepreneurship requires motivation, opportunity, and resources, and these three elements can be present at the group level even when they are not at the level of its individual members (when considered solo). The social dynamics linking individuals can motivate engagement and the shared references tied to the group can inspire opportunity identification. In addition, the evidence shows the relevance of looking at the group as enabling institutional entrepreneurship by facilitating or not facilitating access to the support and resources required to advance institutional efforts. Table 3 provides a summary of the findings.

\section{Discussion of Findings, Implications, and Future Research}

This paper asks why individuals are willing to engage in institutional entrepreneurship. The exploration of this question conducted in the context of the emergence of commercial microfinance in Bolivia suggests that it is crucial to consider this question at the meso-group level of analysis. Prior research has acknowledged the role of one meso-level factor, namely linkages 
Table 3. The social group as stage for individual engagement in institutional entrepreneurship.

Motivating engagement

Inspiring opportunity identification

Enabling access to support and resources
The group stage fuels individuals' will to assume the risks and costs involved.

The group stage allows individuals to appreciate alignments between their interests and field conditions invisible to non-members.

The group stage defines access to resources and support to advance institutional initiatives.

among individuals, but only considering their influence as a source of resources and support (Owen-Smith \& Powell, 2008) to advance institutional efforts (Aldrich \& Fiol, 1994). But in the institutional entrepreneurship efforts studied, the group stage emerged as central both to motivation and opportunity identification. It also played a role in enabling access to resources and support, but this role was subsidiary; it explained only which institutional entrepreneurship initiatives advanced (those which could advance relying on individuals' social capital or those occurring within an institutional context that facilitated resource mobilization), while others fail to do so.

The paper then advances an inhabited institutions (Bechky, 2011; Everitt, 2012; Haedicke, 2012; Hallett \& Ventresca, 2006) understanding of institutional entrepreneurship and argues for the adoption of the small group (Fine, 1979), the prototype meso-level unit of analysis, to explore why individuals will (instead of why individuals can) engage in institutional entrepreneurship. This reorientation from the micro- to the meso-level of analysis alleviates the need for the heroic conceptualizations that populate most research on institutional entrepreneurship. Institutional entrepreneurs do not need to be heroes, with superhuman foresight and enough resources to spark processes of institutional change. They need only to inhabit a group stage that simultaneously motivates, inspires and enables engagement in institutional entrepreneurship. Such group stages may be rare, the product of unexpected, momentous, and/or serendipitous circumstances, but their inhabitants do not need to possess the kind of superhuman qualities currently associated with institutional entrepreneurs (see also Dorado \& Ventresca, 2012).

The proposal to adopt the small group as the unit of analysis of reference implies a rethinking of the methodological individualism (Coleman, 1986) defining institutional entrepreneurship scholarship on the linking of micro-actions and macro-outcomes. The value of methodological individualism is that it assures that individuals regain their centrality after they have all but disappeared from organizational institutionalism (Jepperson \& Meyer, 2011; Lawrence et al., 2010, pp. 53-54). The problem of methodological individualism is what Willmott (2011) has described as its voluntaristic bias, that is, that even though our understanding of institutions builds on the insight that individuals cannot escape the institutions framing their behavior, we explain individuals' engagement in institutional entrepreneurship suggesting that it is possible only when individuals do escape the cognitive influence of institutions. By adopting the small group as the unit of analysis, we can overcome this bias as it explains engagement, without escaping the institutions framing their cognition, by pointing to the historicity and sociality of individuals' decisions to engage in institutional entrepreneurship.

Lack of historicity (Granovetter, 1992) plagues most research linking individual efforts and macro-outcomes (Harrington \& Fine, 2006). In the institutional entrepreneurship literature, this problem has been acknowledged (Emirbayer \& Mische, 1998; Lawrence et al., 2001, 2010). Still, by and large, our current conceptualizations suggest that individuals identify opportunities for engagement as if in a temporal vacuum. The process hinges only on the alignment, or lack thereof, between individuals' interests and field logics. From this perspective, people are expected to 
identify opportunities for engagement only when there is misalignment or when the existing alignment is under threat (Hensmans, 2003). Adopting the small group, in contrast, highlights that the inspiration for opportunity identification is path dependent. Current decisions depend both on past interactions as well as individuals' expectations of future ones. Within a pathdependent history of interactions, decisions that, without it, may appear to be unusual (e.g. in Bolivia it was unusual for NGOs to have boards of directors independent from managers), unwarranted (e.g. using commercial funds to finance the operations of an organization serving the poor), and even deviant (e.g. an NGO launching a commercial bank) emerge as a judicious next step in a stream of decision-making.

Researchers have suggested that, without abandoning the individual as the unit of analysis, we can gain historicity when we conceptualize individuals considering not only their skills and interests but also their personal biography (Lawrence et al., 2010). But adopting the small group has the additional advantage of facilitating observation of the influence of social dynamics (e.g. interpersonal bonds, status calculations) which otherwise frame individual decision-making processes.

First, up until now, institutional entrepreneurship research has acknowledged the value of people's interpersonal connections as relevant to leverage resources and support. In contrast, this paper suggests that the group is irremediably enmeshed with individuals' will to engage and that its influence in mobilizing support and resources explains not the likelihood of their engagement but whether that engagement translates into field change. This insight needs to be further explored and confirmed with research projects that, like this one, consider not only institutional entrepreneurial initiatives that do generate the field change desired by their promoters but also those that fail to generate it.

Second, adopting the small group allows us to expand our understanding of the conditions that motivate individuals to assume the costs and risks of engaging in institutional entrepreneurship. People may be motivated to pursue an individual interest (the only source of motivation currently acknowledged in the institutional literature), but they may also be motivated to engage at the service of other individuals with whom they are tightly connected. Incorporating interpersonal bonds as a source of motivation is relevant because it helps explain the engagement in institutional entrepreneurship of individuals who, like Romero, may have the profile and resources to do it but lack the a priori motivation to get involved and may do so only when convened (Dorado, 2005 ) by others. This insight calls for research which problematizes who is the institutional entrepreneur. It may be that the institutional entrepreneur is not a solo individual with the foresight, skill and resources to advance a highly valued interest but participants in a small group which motivates, inspires, and enables engagement.

Third and finally, adopting the small group pushes researchers to consider social dynamics other than interpersonal bonds - for example, status competition - as relevant motivation for individuals to engage in institutional entrepreneurship. The institutional literature has acknowledged the influence of status calculations in individuals' decisions to engage (Battilana, 2006). But by disregarding the influence of the group stage on how individuals identify their status competitors, this research cannot explain differences in motivation among individuals with similar field positioning (e.g. the local NGO professionals running organizations providing loans to the poor). In contrast, by adopting the small group we can explore differences in engagement considering differences in the stage framing their decision-making. The identification of competition for social status as a relevant dynamic emerged from the evidence, but there may be other social dynamics that are relevant in other settings. The sources can be varied and include social dynamics explored in the social psychology literature, for example, gossip (Fine \& Rosnow, 1978) or envy (Schoeck, 1987).

The relevance of the small group to advance our understanding of institutional entrepreneurship emerged inductively from the study. The empirical setting, however, was rather specific in 
ways that may be hard to replicate in other studies. La Paz, Bolivia's capital city and the stage where commercial microfinance emerged, is a rather small social space. At the time data was being collected for this study, it was common for the promoters and managers of microfinance organizations to meet, casually at a restaurant or club in La Paz or, per the invitation of a donor organization, at a microfinance forum in Washington, DC, or in Frankfurt, Germany. The tightness of this social space facilitated, in the manner of a "Petri dish", to observe and understand the clustering of individuals along boundaries of small groups that did not respect organizational or socio-demographic boundaries - something difficult to appreciate in most field contexts owing to the considerable number and geographic dispersion of sites (Barley \& Tolbert, 1997).

Nonetheless, considering the ubiquity of small groups, the research proposals advanced in this paper might be useful to explore institutional entrepreneurship within more restricted collectives, such as organizations. Current research on inhabited institutions provides a good starting point (see, e.g., Binder, 2007; Hallett, 2010) for this research program.

In finishing, it is important to mention that the idea of using the small group as the preferred unit of analysis to explore the interplay of micro-actions and macro-outcomes has been proposed in the context of research on civic engagement (Fine \& Harrington, 2004; Fine, 2010). The findings of this paper regarding its centrality to understand individual engagement in institutional entrepreneurship call attention to the need to explore the potential overlap between these two concepts. An action is considered civic engagement when it concerns advancing a collective instead of a private interest; collective interests involve hard-to-privatize desired outcomes. This condition is not required for institutional entrepreneurial actions. Instead, an action is considered institutional entrepreneurship when it advances, changes, or undermines institutional practices, logics, and structures. Nevertheless, the actions identified in this paper and others identified both in the literature on civic engagement (see, e.g., Gould's (1993) study of 19th-century French working-class protests, or Opp and Gern's (1993) research on the tearing down of the Berlin Wall) and the literature on institutional entrepreneurship (see, e.g., Rao's (1998) work on consumerwatchdog organizations or Maguire and colleagues' (2004) research, on HIV/AIDS treatment advocacy) do both; they advance collective interests and have institutional impact. This recognition points to the need for research exploring whether all or only some institutional entrepreneurial actions can be fairly described as forms of civic engagement. The potential theoretical benefits of such research are substantial, including a clarification of the current rather blurred distinction between entrepreneurial and institutional entrepreneurial actions. A large overlap would imply that we could define institutional entrepreneurial actions as those entrepreneurial actions with hard-to-privatize outcomes.

\section{Acknowledgements}

This manuscript benefited from rich and detailed comments from Ebony N. Bridwell-Mitchel. Prior versions of this manuscript received feedback from several colleagues including Ted Baker, Tim Hallett, Anand Narasimham, William Ocasio, and Marc Ventresca. A prior version, submitted to the 2010 Academy of Management annual conference, won the Academy of Management Conference Carolyn Dexter Award for the best international paper.

\section{Note}

1. Pasanakus are a type of rotational savings and credit association that periodically allocate to one member a preset amount of money. In urban areas, they are often run by brokers who charge fees equivalent to interest rates in excess of $100 \%$. 


\section{Funding}

Fieldwork for this project was conducted with the generous financial support of Interdisziplinary Projekt Consult (IPC).

\section{References}

Aldrich, H. E., \& Fiol, C. M. (1994). Fools rush in? The institutional context of industry creation. The Academy of Management Review, 19/4, 645-670.

Aldrich, H. E., \& Ruef, M. (2006). Organizations evolving. London: SAGE Publications.

Barley, S. R. (1986). Technology as an occasion for structuring: Evidence from observations of CT scanners and the social order of radiology departments. Administrative Science Quarterly, 31/1, pp. 78-108.

Barley, S. R., \& Tolbert, P. S. (1997). Institutionalization and structuration: Studying the links between action and institution. Organization Studies, 18/1, 93.

Battilana, J. (2006). Agency and institutions: The enabling role of individuals' social position. Organization, $13 / 5,653-676$.

Battilana, J., \& Dorado, S. (2010). Building sustainable hybrid organizations: The case of commercial microfinance organizations. Academy of Management Journal, 53/6, 1419-1440.

Battilana, J., Leca, B., \& Boxenbaum, E. (2009). How actors change institutions: Towards a theory of institutional entrepreneurship. Academy of Management Annals, 3/1, 65-107.

Bechky, B. A. (2011). Making organizational theory work: Institutions, occupations, and negotiated orders. Organization Science, 22/5, 1157-1167.

Becker, H. S. (1984). Art worlds. Berkeley, CA: University of California Press.

Binder, A. (2007). For love and money: Organizations' creative responses to multiple environmental logics. Theory and Society, 36/6, 547-571.

Blumer, H. (1986). Symbolic interactionism: Perspective and method. Berkeley, CA: University of California Press.

Bourdieu, P. (1990). The logic of practice. Stanford, CA: Stanford University Press.

Christen, R. (1985). Programa de apoyo a la microempresa: Estudio de factibilidad para La Paz, Bolivia. Cambridge, MA: ACCION International.

Coleman, J. S. (1986). Social theory, social research, and a theory of action. American Journal of Sociology, 91/6, 1309-1335.

Colyvas, J. A., \& Powell, W. W. (2006). Roads to institutionalization: The remaking of boundaries between public and private science. Research in Organizational Behavior: An Annual Series of Analytical Essays and Critical Reviews, 27, 305-353.

Dacin, M. T., Goodstein, J., \& Scott, W. R. (2002). Institutional theory and institutional change: Introduction to the special research forum. Academy of Management Journal, 45/1, 43-56.

Deutsch, M. (1949). An experimental study of the effects of co-operation and competition upon group process. Human Relations, 2/3, 199-232.

Dewey, J. (1985). The logic of judgments of practice. In J. A. Boydston (Ed.), John Dewey: Essays on education and politics (pp. 14-82). Carbondale: Southern Illinois University Press.

DiMaggio, P. (1988). Interest and agency in institutional theory. In L. G. Zucker (Ed.), Institutional Patterns and Organizations (pp. 3-21). Cambridge, MA: Ballinger.

DiMaggio, P. (1991). Constructing an organizational field as a professional project: US art museums, 1920-1940. In W. W. Powell \& P. J. DiMaggio (Eds.), The new institutionalism in organizational analysis (pp. 267-292). Chicago, IL: University of Chicago Press.

Dorado, S. (2005). Institutional entrepreneurship, partaking, and convening. Organization Studies, 26/3, 385-414.

Dorado, S., \& Ventresca, M. J. (2012). Crescive entrepreneurship in complex social problems: Institutional conditions for entrepreneurial engagement. Journal of Business Venturing, 28, 69-82.

Douglas, M. (1986). How institutions think. Syracuse, NY: Syracuse University Press.

Eisenhardt, K. M., \& Bourgeois, L. J. (1988). Politics of strategic decision making in high-velocity environments: Toward a midrange theory. Academy of Management Journal, 31/4, 737-770. 
Emirbayer, M. (1997). Manifesto for a relational sociology. American Journal of Sociology, 103/2, 281-317. Emirbayer, M., \& Mische, A. (1998). What is agency? American Journal of Sociology, 103/4, 962-1023.

Espeland, W. N. (1998). The struggle for water: Politics, rationality, and identity in the American Southwest. Chicago, IL: University of Chicago Press.

Everitt, J. G. (2012). Teacher careers and inhabited institutions: Sense-making and arsenals of teaching practice in educational institutions. Symbolic Interaction, 35/2, 203-220.

Festinger, L. (1957). A theory of cognitive dissonance. Evanston, IL: Row \& Peterson.

Fidler, P. (1998). Bolivia: Assessing the performance of Banco Solidario (Case Studies in Microfinance, Sustainable Banking with the Poor). Washington, DC: World Bank.

Fine, G. A. (1979). Small groups and culture creation: The idioculture of Little League baseball teams. American Sociological Review, 44/5, 733-745.

Fine, G. A. (2010). The sociology of the local: Action and its publics. Sociological Theory, 28/4, 355-376.

Fine, G. A., \& Harrington, B. (2004). Tiny publics: Small groups and civil society. Sociological Theory, 22/3, 341-356.

Fine, G. A., \& Rosnow, R. L. (1978). Gossip, gossipers, gossiping. Personality and Social Psychology Bulletin, 4/1, 161-168.

Fiske, S. T., \& Taylor, S. E. (1991). Social cognition. New York: McGraw-Hill Book Company.

Frankiewicz, C. (2001). Building institutional capacity: The story of Prodem. Toronto: Calmedow Foundation.

Friedland, R., \& Alford, R. R. (1991). Bringing society back in: Symbols, practices, and institutional contradictions. In W. W. Powell \& P. J. DiMaggio (Eds.), The new institutionalism in organizational analysis (pp. 232-263). Chicago: University of Chicago Press.

Giddens, A. (1984). The constitution of society: Outline of the theory of structuration. Berkeley, CA: University of California Press.

Gloser, A. J. (1994). The creation of BancoSol in Bolivia. In M. Otero \& E. Rhyne (Eds.), The new world of microenterprise finance (pp. 229-249). West Hartford, CT: Kumarian Press.

Glynn, M. A. (2000). When cymbals become symbols: Conflict over organizational identity within a symphony orchestra. Organization Science, 11/3, 285-298.

Goffman, E. (1963). Stigma. New York: Simon \& Schuster.

Goffman, E. (1974). Frame analysis: An essay on the organization of experience. Boston, MA: Harvard University Press.

Gonzales, G., \& Rivas, H. (1999). Las ONG's Bolivianas en las microfinanzas. La Paz, Bolivia: SINERGIA.

Gonzalez-Vega, C., Schreiner, R. L., Meyer, R. L., Rodriguez, J., \& Navajas, S. (1996). BancoSol: The challenge of growth for microfinance organizations. Ohio State University, Columbus, $\mathrm{OH}$, Economics and Sociology Occasional Paper 2332.

Gould, R. V. (1993). Trade cohesion, class unity, and urban insurrection: Artisanal activism in the Paris Commune. American Journal of Sociology, 58/4, 721-754.

Granovetter, M. (1978). Threshold models of collective behavior. American Journal of Sociology, 83/6, $1420-1443$.

Granovetter, M. (1992). Problems of explanation in economic sociology. In N. Nohria \& R. G. Eccles (Eds.), Networks and organizations: Structure, form, and action (pp. 25-56). Boston, MA: Harvard Business School.

Greenwood, R., \& Hinings, C. R. (1993). Understanding strategic change: The contribution of archetypes. Academy of Management Journal, 1052-1081.

Greenwood, R., \& Suddaby, R. (2006). Institutional entrepreneurship in mature fields: The big five accounting firms. The Academy of Management Journal, 49/1, 27-48.

Greenwood, R., Raynard, M., Kodeih, F., Micelotta, E. R., \& Lounsbury, M. (2011). Institutional complexity and organizational responses. The Academy of Management Annals, 5/1, 317-371.

Haedicke, M. A. (2012). Keeping our mission, changing our system: Translation and organizational change in natural food co-ops. The Sociological Quarterly, 53/1, 44-67.

Hallett, T. (2010). The myth incarnate. American Sociological Review, 75/1, 52-74.

Hallett, T., \& Ventresca, M. J. (2006). Inhabited institutions: Social interactions and organizational forms in Gouldner's patterns of industrial bureaucracy. Theory and Society, 35/2, 213-236. 
Harrington, B., \& Fine, G. A. (2000). Opening the 'black box': Small groups and twenty-first-century sociology. Social Psychology Quarterly, 63/4, 312-323.

Harrington, B., \& Fine, G. A. (2006). Where the action is small groups and recent developments in sociological theory. Small Group Research, 37/1, 4-19.

Heclo, H. (2008). On thinking institutionally. Boulder, CO: Paradigm Publications.

Heimer, C. A. (1999). Competing institutions: Law, medicine, and family in neonatal intensive care. Law \& Society Review, 33/1, 17-66.

Hensmans, M. (2003). Social movement organizations: A metaphor for strategic actors in institutional fields. Organization Studies, 24/3, 355-381.

Ibarra, H., Kilduff, M., \& Tsai, W. (2005). Zooming in and out: Connecting individuals and collectivities at the frontiers of organizational network research. Organization Science, 16/4, 359-371.

Janis, I. L. (1982). Groupthink: Psychological studies of policy decisions and fiascos. Boston: Houghton Mifflin.

Jemio, L. C. (1999). Reformas, politicas sociales y equidad en Bolivia. Santiago, Chile: E.C.L.A.C.

Jepperson, R., \& Meyer, J. W. (2011). Multiple levels of analysis and the limitations of methodological individualisms. Sociological Theory, 29/1, 54-73.

Kellogg, K. C. (2009). Operating room: Relational spaces and microinstitutional change in surgery. American Journal of Sociology, 115/3, 657-711.

Korsgaard, M. A., Schweiger, D. M., \& Sapienza, H. J. (1995). Building commitment, attachment, and trust in strategic decision-making teams: The role of procedural justice. Academy of Management Journal, $38 / 1,60-84$.

Lawrence, T. B., \& Suddaby, R. (2006). Institutions and institutional work. In S. Clegg, C. Hardy, \& W.R. Nord (Eds.), The SAGE Handbook of Organization Studies (pp. 215-254). Thousand Oaks, CA: SAGE Publications.

Lawrence, T. B., Winn, M. I., \& Jennings, P. D. (2001). The temporal dynamics of institutionalization. Academy of Management Review, 26/4, 624-644.

Lawrence, T., Suddaby, R., \& Leca, B. (2010). Institutional work: Refocusing institutional studies of organization. Journal of Management Inquiry, 20/1, 52-58.

Leblebici, H., Salancik, G. R., Copay, A., \& King, T. (1991). Institutional change and the transformation of interorganizational fields: An organizational history of the U.S. radio broadcasting industry. Administrative Science Quarterly, 36/3, 333-363.

Lounsbury, M. (2007). A tale of two cities: Competing logics and practice variation in the professionalizing of mutual funds. The Academy of Management Journal, 50/2, 289-307.

Lounsbury, M., Ventresca, M., \& Hirsch, P. (2003). Social movements, field frames and industry emergence: A cultural-political perspective on US recycling. Socio-Economic Review, 1, 71-104.

Maguire, S., Hardy, C., \& Lawrence, T. B. (2004). Institutional entrepreneurship in emerging fields: HIV/ AIDS treatment advocacy in Canada. The Academy of Management Journal, 47/5, 657-679.

Mead, G. H. (1967). Mind, self, and society: From the standpoint of a social behaviorist (Vol. 1). Chicago, IL: University of Chicago Press.

Meyer, J. W., \& Rowan, B. (1977). Institutionalized organizations: Formal structure as myth and ceremony. The American Journal of Sociology, 83/2, 340-363.

Nimal, A. (2004). Micro success story? Transformation of nongovernmental organizations into regulated financial institutions. Asian Development Bank, Regional and Sustainable Development Department.

Ocasio, W. (1997). Towards an attention-based view of the firm. Strategic Management Journal, 18, 187-206.

Opp, K. D., \& Gern, C. (1993). Dissident groups, personal networks, and spontaneous cooperation: The East German revolution of 1989. American Sociological Review, 58/5, 659-680.

Owen-Smith, J., \& Powell, W. W. (2008). Networks and institutions. In R. Greenwood, C. Oliver, K. SahlinAndersson \& R. Suddaby (Eds.), The SAGE handbook of organizational institutionalism (pp. 596-623). New York: SAGE Publications.

Phillips, N., Lawrence, T. B., \& Hardy, C. (2000). Inter-organizational collaboration and the dynamics of institutional fields. Journal of Management Studies, 37/1, 23-43.

Ragin, C. C. (1994). Constructing social research: The unity and diversity of method. Thousand Oaks, CA: Pine Forge Press. 
Ramirez, P. (1998). Fondo financiero privado FIE SA. Seminar reader of the Second Annual Seminar on New Development Finance. Goethe University.

Rao, H. (1998). Caveat emptor: The construction of nonprofit consumer watchdog organizations. The American Journal of Sociology, 103/4, 912-961.

Rhyne, E. (2001). Mainstreaming microfinance: How lending to the poor began, grew, and came of age in Bolivia. Bloomfield, CT: Kumarian Press.

Schneiberg, M. (2007). What's on the path? Path dependence, organizational diversity and the problem of institutional change in the US economy, 1900-1950. Socio-Economic Review, 5/1, 47-80.

Schneiberg, M., \& Clemens, E. S. (2006). The typical tools for the job: Research strategies in institutional analysis. Sociological Theory, 24/3, 195-227.

Schoeck, H. (1987). Envy: A theory of social behavior. Indianapolis, IN: Liberty Fund.

Schön, D. A. (1979). Generative metaphor: A perspective on problem-setting in social policy. Metaphor and thought. Cambridge: Cambridge University Press.

Schütz, A. (1962). Choosing among projects of action. In M. A. Natanson (Ed.), Collected papers: The problem of social reality (Vol. 1, pp. 67-96). The Hague: Martinus Nijhoff Publishing.

Scott, W. R. (2008). Institutions and organizations: Ideas and interests. Los Angeles, CA: SAGE Publications.

Seo, M. G., \& Creed, W. E. D. (2002). Institutional contradictions, praxis, and institutional change: A dialectical perspective. The Academy of Management Review, 27/2, 222-247.

Stark, D. (1996). Recombinant property in East European capitalism. The American Journal of Sociology, $101 / 4,993-1027$.

Stark, D. (2009). The sense of dissonance: Accounts of worth in economic life. Princeton, NJ: Princeton University Press.

Strauss, A. L., \& Corbin, J. M. (1998). Basics of qualitative research: Techniques and procedures for developing grounded theory. Thousand Oaks, CA: SAGE Publications.

Swidler, A. (1986). Culture in action: Symbols and strategies. American Sociological Review, 51/2, 273-286.

Thornton, P. H. (2004). Markets from culture: Institutional logics and organizational decisions in higher education publishing. Stanford, CA: Stanford University Press.

Veblen, T. (1970). The theory of the leisure class. London: Unwin Books.

Washington, M., \& Zajac, E. J. (2005). Status evolution and competition: Theory and evidence. Academy of Management Journal, 48/2, 282-296.

Weber, M. (1978). Economy and society: An outline of interpretive sociology. In G. Roth \& C. Wittich (Eds.), Readings in economic sociology (pp. 24-37). Berkeley, CA: University of California Press.

Weick, K. E. (1993). The collapse of sensemaking in organizations: The Mann Gulch disaster. Administrative Science Quarterly, 38, 628-652.

Whittington, R. (1992). Putting Giddens into action: Social systems and managerial agency. Journal of Management Studies, 29/6, 693-712.

Willmott, H. (2011). 'Institutional work' for what? Problems and prospects of institutional theory. Journal of Management Inquiry, 20/1, 67-72.

Zilber, T. B. (2002). Institutionalization as an interplay between actions, meanings, and actors: The case of a rape crisis center in Israel. The Academy of Management Journal, 45/1, 234-254.

\section{Author biography}

Silvia Dorado is associate professor of management at the University of Rhode Island. Her research explores processes of entrepreneurship in the context of social change including the emergence and survival of socioeconomic hybrid organizations. Silvia received her BA degree from Universidad Autónoma de Madrid (Spain), her MA from the Massachusetts Institute of Technology (USA), and her PhD from McGill University (Canada). 